\title{
WSPIERANIE ZATRUDNIENIA OSÓB Z NIEPEŁNOSPRAWNOŚCIAMI W ŚWIETLE KONCEPCJI ARTHURA PIGOU I RONALDA COASE
}

\section{SYSTEM OF EMPLOYMENT OF PEOPLE WITH DISABILITIES IN THE LIGHT OF THE CONCEPTS BY ARTHUR PIGOU AND RONALD COASE}

\author{
Marcin Garbat ${ }^{1(\mathrm{~A}, \mathrm{~B}, \mathrm{C}, \mathrm{D}, \mathrm{E}, \mathrm{F}, \mathrm{G})}$ \\ ${ }^{1}$ Uniwersytet Zielonogórski
}

\begin{abstract}
Garbat, M. (2018). Wspieranie zatrudnienia osób z niepełnosprawnościami w świetle koncepcji Arthura Pigou i Ronalda Coase. Rozprawy Społeczne, 12(2), 23-31. https://doi.org/10.29316/rs.2018.13
\end{abstract}

\author{
Wkład autorów: \\ A. Zaplanowanie badań \\ B. Zebranie danych \\ C. Dane - analiza i statystyki \\ D. Interpretacja danych \\ E. Przygotowanie artykułu \\ F. Wyszukiwanie i analiza \\ literatury \\ G. Zebranie funduszy
}

Tabele: 1

Ryciny: 0

Literatura: 24

Otrzymano: styczeń 2018

Zaakceptowano: kwiecień 2018

\begin{abstract}
Streszczenie
W 1960 r. ekonomista Ronald Coase opublikował artykuł pt. „Problem kosztów społecznych”, który do dziś jest jednym z najczęściej cytowanych tekstów ekonomicznych i nadal wzbudza żywe dyskusje. Napisał tam, że problem kosztów zewnętrznych ma dwojaką naturę: negatywne efekty zewnętrzne generowane przez jeden podmiot przynoszą drugiemu stratę, lecz zakazanie szkodzenia jest automatycznie strata dla pierwszego. Argumentował, że w przypadku dobrze zdefiniowanych praw własności i niskich kosztów transakcyjnych problem efektów zewnętrznych może być rozwiązany poprzez transakcje pomiędzy stronami, których te efekty dotyczą. Stało to $\mathrm{w}$ opozycji do wcześniejszych prób rozwiazania tego problemu poprzez regulację rządowa lub opodatkowanie zaproponowane przez Arthura Pigou. W istocie - patrząc przez pryzmat systemu wspierania zatrudnienia osób z niepełnosprawnościami - rozwiązanie sprowadza się do rozstrzygnięcia: czy opłaca się ograniczyć zatrudnienie osób sprawnych lub zasoby finansowe pracodawców, aby zapewnić pracę mniej wydajnym osobom z niepełnosprawnościami, czy pozostawić te osoby bez wsparcia na rynku pracy. W każdym przypadku chodzi o wyrządzenie jak najmniejszej szkody społecznej. W niniejszym artykule przedstawiono obie koncepcje na przykładzie systemu wspierania zatrudnienia osób z niepełnosprawnościami w Polsce.
\end{abstract}

Słowa kluczowe: osoba z niepełnosprawnościami, system wspierania zatrudniania, teoremat Coase, podatek Pigou

\section{Summary}

In 1960, Economist Ronald Coase published the article entitled „The Problem of Social Costs”, which is still one of the most frequently cited economic texts raising heated discussions. He wrote that the problem of external costs is twofold, i.e. concerning external effects generated by one entity causing loss for another, where the suppression of injustice is automatically a loss for the first one. He argued that in the case of well-defined property rights and low transaction costs, the problem of external effects can be solved through transactions between parties affected by these effects. Such an understanding of the issue was in opposition to the former attempts to solve this problem through governmental regulation or taxation proposed by Arthur Pigou. In fact, looking through the prism of the system of supporting employment of people with disabilities, the solution causes a dilemma whether it is profitable to limit the employment of efficient people or financial resources of employers in order to provide work for less-efficient people with disabilities, or to leave these people without support on the labour market. In each case, it is about doing the least possible social damage. This article presents both concepts on the example of the system of supporting the employment of people with disabilities in Poland.

Keywords: persons with disabilities, employment, support system, Coase theorem, Pigou tax

\section{Wprowadzenie}

W połowie XX w. przedstawiciele głównego nurtu ekonomii w przeciwieństwie do przedstawicieli szkoły klasycznej coraz częściej skupiali uwagę na zawodności nieograniczonego rynku. Za istotny czynnik zawodności mechanizmu „niewidzialnej ręki” uważali efekty zewnętrzne, coraz bardziej widoczne wraz z postępem technicznym i społecznym. Stanowisko ortodoksyjnej koncepcji z drugiej dekady XX w. zostało oparte na analizie Arthura Cecila Pigou (1887-1959) - znanego brytyjskiego ekonomisty. Proponował on rozwiązanie kwestii „różnicy pomiędzy produktem społecznym a prywatnym" - znanym dzisiaj jako problem efektów zewnętrznych - wprowadzeniem przez państwo odpowiednich podatków, danin lub opłat. Przez pół wieku jego koncepcja była uznawana lub krytykowana przez przedstawicieli różnych szkół ekonomicznych, ale nikt nie odważył się jasno i wyraźnie

Adres korespondencyjny: Marcin Garbat, Pełnomocnik Rektora ds. Niepełnosprawnych Studentów, Uniwersytet Zielonogórski, al. Wojska Polskiego 69, 65-417 Zielona Góra, e-mail: M.Garbat@adm.uz.zgora.pl, tel. 683283179

Copyright by: Państwowa Szkoła Wyższa im. Papieża Jana Pawła II w Białej Podlaskiej, Marcin Garbat

Czasopismo Open Access, wszystkie artykuły udostępniane są na mocy licencji Creative Commons Uznanie autorstwa-użycie niekomercyjne-na tych samych warunkach 4.0 Międzynarodowe (CC BY-NC-SA 4.0, http://creativecommons.org/licenses/by-nc-sa/4.0/). 
jej poważyć, na tyle jasno, aby było to uważane za kontrargument. Dopiero w 1960 r. pojawiło się nowatorskie rozwiązanie owego problemu autorstwa Ronalda Harrego Coase (1910-2013) laureata Nagrody Banku Szwecji im. Alfreda Nobla. Stanowisko to jest rozumiane jako prorynkowe, ponieważ zgodnie $\mathrm{z}$ jego założeniami sam rynek bez ingerencji instytucji państwa jest w stanie - pod warunkiem niskich kosztów transakcyjnych - poradzić sobie z problem efektów zewnętrznych poprzez negocjacje. W artykule przedstawiono obie koncepcje na przykładzie systemu wspierania zatrudnienia osób z niepełnosprawnościami w Polsce.

\section{Bezrobocie oraz niska aktywność zawodowa osób z niepełnosprawnościami jak tło problemu}

Wyniki Badania Aktywności Ekonomicznej Ludności (tabela 1) wskazują, że po okresowej stabilizacji wartości wskaźnika zatrudnienia osób z niepełnosprawnościami w latach 2013-2015 wieku produkcyjnym, wynoszącego około 23\%, w 2016 r. nastąpił jego wzrost do poziomu - 23,7\%. Ponadto w 2016 r. zanotowano obniżenie się poziomu stopy bezrobocia osób z niepełnosprawnościami w wieku produkcyjnym do 11,6\%. Oznacza to, że stopa bezrobocia obniżyła się o 1,4\% w stosunku do roku poprzedniego oraz o 4,5\% w stosunku do 2014 r. (BAEL, 2017).

Od 2007 r. można zaobserwować również stopniowy wzrost współczynnika aktywności zawodowej do 28\% w 2012 r. oraz utrzymywanie się jego wartości na stabilnym poziomie około $27 \%$ w latach 2013-2014. W 2015 r. wielkość współczynnika spadła do poziomu 26,8\%, natomiast w 2016 r. do 26,1\%. W 2017 r. współczynnik wzrósł o niemal 4\% i osiągnął wartość 29,9\%. Wartość współczyn- nika aktywności zawodowej jest ściśle związana zarówno z liczbą osób pracujących jak i bezrobotnych, a przekroczenie progu $27 \%$ tego wskaźnika w latach 2012-2014 było spowodowane wzrostem bezrobocia. Tymczasem w 2017 r. zwiększenie wartości współczynnika było pochodną wzrostu zatrudnienia.

Należy zauważyć, iż wartość współczynnika aktywności zawodowej - w każdym z omawianych okresów - jest trzykrotnie niższy, niż u osób sprawnych (kształtującym się na poziomie 79,9\% w 2017 r.), oraz o kilkanaście procent niższy niż w innych krajach Unii Europejskiej (Garbat 2012, s. 134). Analogicznie stopa bezrobocia jest dwukrotnie wyższa, niż u osób sprawnych (4,8\% w 2017 r.). Niska aktywność zawodowa oraz wysoka stopa bezrobocia osób z niepełnosprawnościami jest problemem ryku pracy w Polsce. Stanowi to wielkie wyznawanie dla instytucji i organizacji odpowiedzialnych za kształtowanie polityki społecznej.

\section{Podatek Arthura Cecila Pigou}

Pojęcie efektu zewnętrznego pojawiło się w ekonomii na przełomie XIX i XX w. Ale przez długie lata nie było traktowane poważnie. Dopiero w połowie XX w. - głównie za sprawą katastrofalnego stanu środowiska przyrodniczego - uwiadomiono sobie, że jest to zjawisko o bardzo szerokich skutkach. Kalkulacje i analizy wykazały, że gospodarki poszczególnych państw tracą znaczny odsetek swojego PKB. Zadano sobie wtedy pytanie, co robić w sytuacji, gdy rynek nie ma szans ukazać swoich zalet na skutek istnienia owych efektów zewnętrznych? Rynek czasem nie działa dobrze - mechanizm rynkowy zawodzi i trzeba interweniować. Pierwszym pomysłem na taką ingerencję państwa

Tabela 1. Aktywność zawodowa osób sprawnych i z niepełnosprawnościami w wieku produkcyjnym w Polsce w latach 2007-2017

\begin{tabular}{|c|c|c|c|c|c|c|c|c|}
\hline \multirow{3}{*}{ Rok } & \multicolumn{2}{|c|}{ Pracujący } & \multicolumn{2}{|c|}{$\begin{array}{c}\text { Współczynnik } \\
\text { aktywności zawodowej }\end{array}$} & \multicolumn{2}{|c|}{$\begin{array}{c}\text { Wskaźnik } \\
\text { zatrudnienia }\end{array}$} & \multicolumn{2}{|c|}{$\begin{array}{c}\text { Stopa } \\
\text { bezrobocia }\end{array}$} \\
\hline & OS* & $\mathbf{0 z N} * *$ & OS* & $\mathbf{O z N} * *$ & OS & $\mathbf{O z N}$ & OS & $\mathbf{O z N}$ \\
\hline & \multicolumn{2}{|c|}{ Tys. } & \multicolumn{2}{|c|}{$\%$} & \multicolumn{2}{|c|}{$\%$} & \multicolumn{2}{|c|}{$\%$} \\
\hline 2007 & 465 & 14,6 & 74,4 & 23,8 & 68,2 & 20,2 & 8,4 & 15,0 \\
\hline 2008 & 475 & 15,1 & 75,3 & 24,3 & 70,3 & 21,5 & 6,7 & 11,4 \\
\hline 2009 & 457 & 15,0 & 75,8 & 24,5 & 69,3 & 21,7 & 8,5 & 11,6 \\
\hline 2010 & 450 & 14,6 & 76,1 & 26,0 & 69,0 & 22,2 & 9,3 & 14,6 \\
\hline 2011 & 437 & 14,7 & 76,8 & 26,3 & 69,3 & 22,1 & 9,7 & 16,1 \\
\hline 2012 & 448 & 14,7 & 77,4 & 28,0 & 69,5 & 23,2 & 10,1 & 17,2 \\
\hline 2013 & 422 & 14,8 & 78,2 & 26,7 & 70,6 & 21,9 & 9,7 & 18,1 \\
\hline 2014 & 457 & 15,0 & 78,9 & 27,4 & 72,5 & 23,7 & 8,1 & 13,9 \\
\hline 2015 & 434 & 15,2 & 79,0 & 26,8 & 79,0 & 23,5 & 6,9 & 12,3 \\
\hline 2016 & 391 & 15,3 & 79,4 & 26,1 & 79,4 & 23,1 & 6,0 & 11,3 \\
\hline 2017 & 457 & 15,4 & 79,9 & 29,9 & 79,9 & 27,5 & 4,8 & 8,0 \\
\hline
\end{tabular}

*OS - osób sprawnych

**OzN - osób z niepełnosprawnościami

Źródło: Badanie Aktywności Ekonomicznej Ludności BAEL, GUS, 2017, informacja dostępna na stronie internetowej: http:// www.niepelnosprawni.gov.pl/p,81,bael. 
był podatek zaproponowany w 1920 r. przez Pigou i nazwany (Pigouvian Tax). Najogólniej idea podatku kształtuje się następująco: „Skoro rynek jest zawodny przez to, że sprawcą kosztów zewnętrznych udaje się uniknąć odpowiedzialności, przerzucając ciężar na inne podmioty gospodarcze lub państwo (społeczeństwo), to naprawa wymaga obarczenia go tym ciężarem" (Bovenberg, Goulder, 1996, s. 1001). Jego konstrukcja, dopracowana przez kolejnych ekonomistów, polega przede wszystkim na: kalkulacji wartości równej kosztowi zewnętrznemu powodowanemu przez jednostkę działalności przy założeniu, że skala tej działalności jest społecznie optymalna. Obliczoną w ten sposób sumę mnoży się przez pewną ustaloną ilość jednostek tej działalności. Pigou uważał, że ową sumę należałoby pomnożyć przez wszystkie jednostki działalności. Dopiero John Pezzey w latach 80. XX w. zauważył, że wystarczy ją pomnożyć przez ilość jednostek ponad jakiegoś, byleby ustalonego progu. W ten sposób sprawca otrzymuje właściwy bodziec do działania - zlikwidowania lub ograniczenia kosztu zewnętrznego - ponieważ za każdą jego jednostkę płaci podatek. Przedsiębiorcy staje się opłacalne ograniczać swoją działalność tak długo, jak długo jednostkowy koszt tego ograniczenia będzie mniejszy od wartości, która - z definicji - jest równa kosztowi zewnętrznemu przy społecznie optymalnej skali działalności (Bovenberg, Goulder 1996, s. 1009). Widać więc, że podatek Pigou skłania przedsiębiorców do rozwinięcia działalności do poziomu optymalnego ${ }^{1}$. Co ciekawe - mechanizm działa niezależnie od wysokości progu, powyżej którego płaci się podatek Pigou, a poniżej którego otrzymuje się dotację według takiej samej stawki (Pezzey, 1989, 38).

\section{Teoremat Ronalda Coase}

Genezy teorematu Ronalda Coase należy szukać w artykule „The Federal Communications Commission" opublikowanym w Journal of Law \& Economics w 1959 r. Dowodził w nim rynkową alokacją częstotliwości radiowych jako alternatywne rozwiązanie wobec decyzji urzędów. Zaproponował pewną procedurę przyznawania praw własności i ich wymiary, by zapewnić jak najefektywniejsze użycie. Argumentował to w następujący sposób: „jeśli tylko tytuły własności są przyznane, możliwe są negocjacje modyfikujące uwarunkowania prawne, jeśli prawdopodobieństwo ich powodzenia uzasadnia poniesienie kosztów tych negocjacji. Rozgraniczenie (...) tytułów własności jest niezbędnym warunkiem wstępnym transakcji rynkowych. Jednakże ostateczny rezultat (maksymalizujący wartość produkcji) jest nieznany od prawnych rozstrzygnięć" (Coase, 1959, s. 3).

\footnotetext{
1 Optymalna wielkość tzw. podatku Pigou (nazwa pochodzi od nazwiska twórcy tej koncepcji - Arthura Cecila Pigou), czyli opłaty majace doprowadzić do internalizacji kosztu zewnętrznego, wynosi tyle, ile wynoszą koszty zewnętrzne w punkcie ich zrównania się z korzyściami z działalności gospodarczej, za: G. N. Mankiw, M. P. Taylor (2009) Mikroekonomia, Warszawa: PWE, s. 119.
}

Artykuł był sprzeczny z dotychczasowymi poglądami. Dlatego też argumentacja w nim zawarta została uznana za błędną przez przedstawicieli szkoły chicagowskiej. Coase jednak nie przyjął krytyki i postanowił bronić swojego stanowiska. Otrzymał zaproszenie na spotkanie do Aarona Directora - głównego redaktora Journal of Law \& Economics w Chicago, na którym miało dojść do dyskusji na temat błędów dostrzeżonych w jego artykule. Zaproszono również 21 redaktorów czasopisma, w tym: Miltona Friedmana, Georgea Stiglera, Arnolda Herbergera, Johna McGeea oraz Reubena Kessela. Coase zdołał przekonać ich do swojego stanowiska. W efekcie poproszono go o napisanie kolejnego artykułu, w którym po dopracowaniu analizy, miał ponownie zaprezentować swoje poglądy. W ten sposób powstało jedno z najsłynniejszych dzieł w historii myśli ekonomicznej: „The problem of Social Cost". Na 44 stronach Journal of Law \& Economics przedstawił swoja koncepcję - nazwaną Teoreamatem Coase (Kubisz 2017, s.50). Napisał tam, że problem kosztów zewnętrznych ma dwojaką naturę: negatywne efekty zewnętrzne generowane przez jeden podmiot przynoszą drugiemu stratę, lecz zakazanie szkodzenia jest automatycznie stratą dla pierwszego (Coase, 1960, s. 88). W istocie - patrząc przez pryzmat systemu wspierania zatrudnienia osób z niepełnosprawnościami - rozwiązanie sprowadza się do rozstrzygnięcia: czy opłaca się ograniczyć zatrudnienie osób sprawnych lub zasoby finansowe pracodawców, aby zapewnić pracę mniej wydajnym niepełnosprawnym pracownikom, czy pozostawić te osoby bez wsparcia na rynku pracy. W każdym przypadku chodzi o wyrządzenie jak najmniejszej szkody społecznej.

Trzeba jednak pamiętać, że w żadnym z tych artykułów teoremat nie został udowodniony, ani precyzyjnie sformułowany. Dlatego też po analizie założeń teorematu wielu ekonomistów formułuje argumenty dotyczące jego błędności lub poprawności. Jest to związane $\mathrm{z}$ odmiennym rozumienia pojęć - najczęściej kosztu transakcyjnego. W efekcie zbiór owych założeń podlegał ewolucji, co z kolei spowodowało różne jego interpretacje. Przykładem są wątpliwości co do akceptowania przez Coase założenia o doskonałej konkurencji. W odpowiedzi na taką krytykę odrzucił on to założenie, uznając je za nieistotne (Coase, 1988, s. 175).

\section{Regulacja systemu - podatek Pigou i negocjacje Coase}

Większość ekonomistów, takich jak Tom Tietenberg rozważyłby dwie główne teoretyczne koncepcje dotyczące analizy problemu (Tietenberg, 1992, s. 51-69). Pierwsza polega na analizie zewnętrznej, w której pracodawcy nie chcą zatrudniać osób z niepełnosprawnościami, narzucając koszty związane $\mathrm{z}$ ich zatrudnianiem na społeczeństwo. Jest to koszt, który nie wlicza się do rachunku zysków i strat przedsiębiorców - koszt społeczny. Prowadzi 
do zbyt dużej liczby bezrobotnych osób z niepełnosprawnościami i zbyt niskiej ich aktywności zawodowej. Ekonomista wykorzystywałby strukturę analityczną opracowaną przez Pigou (Pigou, 1920).

Druga koncepcja, jaką prawdopodobnie przyjmuje ekonomista, dotyczy osób z niepełnosprawnościami, które chca być aktywne zawodowo lub pracować w ramach konkurencyjnego rynku pracy, na którym ludzie targują się o korzystanie z praw pracowniczych, oraz płacy. Jeśli prawa do aktywów zostaną określone i przydzielone wszystkim podmiotom (pracodawcom, pracownikom i starającym się o pracę), to ci, którzy planują podjąć pracę muszą targować się z pracodawcami, aby, o ile, jeśli w ogóle możliwe, dostać zatrudnienie. Negocjacje określają liczbę zatrudnionych. Podejście to opiera się na pracy Coase (Coase, 1960), który zaproponował inny sposób myślenia o problemie kosztów społecznych. Korzystając z tych założeń, ekonomista może zalecić spotkanie pracodawców i osób z niepełnosprawnościami w celu obustronnych negocjacji.

Zgodnie z teorią Coase, jeżeli zatrudnia się niepełnosprawnych i dotuje ich miejsca pracy, oraz pobiera się daniny (podatki) od pozostałych pracodawców za niezatrudnianie takich osób to tym samym znacząco ogranicza się możliwość zatrudnienia osób sprawnych, a także możliwości rozwoju przedsiębiorstw (poprzez uszczuplenie ich zasobów finansowych na rzecz daniny). Coase argumentował, że w przypadku dobrze zdefiniowanych praw własności i niskich kosztów transakcyjnych problem efektów zewnętrznych może być rozwiązany poprzez transakcje pomiędzy stronami, których te efekty dotyczą. Stoi to w opozycji do wcześniejszych prób rozwiązania tego problemu poprzez regulację rządową lub opodatkowanie zaproponowane przez Pigou, Niektórzy błędnie rozumieją to twierdzenie: że rynki zawsze osiągałyby efektywne wyniki, gdyby koszty transakcyjne były niskie, podczas gdy w rzeczywistości jego punkt myślenia był niemal dokładnie odwrotny: ponieważ koszty transakcyjne nigdy nie będą zerowe, nie można zakładać, że jakiekolwiek instytucjonalne porozumienie będzie koniecznie i wydajne. Dlatego Coase twierdził, że należy zawsze porównywać alternatywne rozwiązania instytucjonalne, aby zobaczyć, które byłoby najbliższe „nieosiągalnemu ideałowi (mitycznego) świata zerowych kosztów transakcyjnych" (Merrill, Smith, 2017, s. 38).

Po wnikliwej analizie ekonomista rozważyłby praktyczne aspekty obu koncepcji. Podejście Pigou nie jest doskonałe ponieważ zdobycie informacji jest kosztowne i wymaga czasu. Niemożliwe jest również określenie optymalnej wielkości podatku, który obciążałby pracodawców i niwelował efekty zewnętrzne, nie pogarszając sytuacji jednej ze stron. Friedrich August von Hayek opisuje obawy Pigou w ten sposób: „Być może jeszcze bardziej pouczający jest przypadek zmarłego profesora AC Pigou, twórcy teorii ekonomii dobrobytu, który pod koniec długiego życia poświęcił się określeniu wa- runków, w których interwencja rządu może zostać wykorzystana w celu poprawy określonej sytuacji. Po analizie efektów rynkowych musiał przyznać, że praktyczna wartość owych rozważań teoretycznych była nieco wątpliwa, ponieważ rzadko jesteśmy w stanie ustalić, czy konkretna okoliczność, do której odnosi się teoria, faktycznie istnieje. Nie dlatego, że ktoś wie o niej wszystko, ale dlatego, że wie tyle, ile powinien wiedzieć, aby skutecznie interweniować" (Hayek, 1969, s 264).

A co zatem z Coase? Podejście Coase teoretycznie rozwiązuje problem związany $\mathrm{z}$ informacja (a raczej jej brakiem), ponieważ zaangażowane strony są decydentami i posiadają wszelkie niezbędne informacje. Jednak jego koncepcja może być nietrafiona z powodu wysokich kosztów transakcyjnych, które powstają, jeśli tysiące niepełnosprawnych zacznie targować się z potencjalnymi pracodawcami. Coase nie opracowywał recepty na politykę państwa w tym zakresie. Wręcz przeciwnie. Wyjaśnia tylko w jaki sposób właściwa interpretacja sił rynkowych opierających się na przepisach prawa mogłaby wyeliminować potrzebę specjalistycznych ustaw dotyczących radzenia sobie $\mathrm{z}$ „problemem kosztów społecznych" (w tym przypadku z niską aktywnością zawodową osób z niepełnosprawnościami). Czyniąc to, zwraca uwagę na instytucje, które ewoluują w celu zmniejszenia nieuchronnych kosztów generowanych w otoczeniu. Regulacje rządowe to tylko jedno z wielu instytucji, jakie można stworzyć. Koszt organizacji i prowadzenia różnych instytucji określa, które, jeśli w ogóle, podejście może być wykorzystane: regulacja rządowa, czy dobrowolne transakcje między stronami. Zamiarem Coase’a było pokazanie, że interwencja rządu, czyli nakładanie podatków na emitentów kosztów zewnętrznych są nieefektywne, ponieważ spory można rozwiązywać za pomocą dobrowolnych negocjacji między stronami. W realnym świecie przy istniejących kosztach transakcyjnych ogromną rolę odgrywa system prawny; od niego zależy definicja własności i sposób przenoszenia jej praw, reguły legislacyjne wpływają zatem bezpośrednio na koszty transakcyjne.

\section{Efekty zewnętrzne, koszty społeczne i koszty transakcyjne}

Instytucje ${ }^{2}$ rynku pracy tworzone są w wyniku społecznych interakcji. Są też warunkami i ograniczeniami działalności gospodarczej podmiotów. Stanowią one element uwarunkowań zewnętrznych gospodarowania, jak i bezpośrednio kształtują preferencje oraz systemy wartości jednostek. Instytucje ułatwiaja przy tym kooperację i koordynację działań podmiotów gospodarczych równolegle do warunków „uczciwej” konkurencji. Analiza insty-

\footnotetext{
2 Pojęcie instytucji autor przyjmuje za Oliverem Williamsonem: 1) Instytucje formalne, 2) nieformalne, 3) reguły zawierania transakcji oraz 4) podmioty - organizacje, za: O.E. Williamson (2000), The New Institutional Economics: Taking Stock, Looking Ahead, Journal of Economic Literature, 38, s. 597.
} 
tucji jest zatem kluczem do zrozumienia procesów zachodzących na każdym rynku, w tym na rynku pracy (Stiglitz, 2004, s. 380).

Otoczenie instytucjonalne wspomaga efektywność gospodarki przez tworzone ograniczenia i bodźce. Jakość instytucji oceniana według kryterium kosztów transakcyjnych, stopnia wypełniania funkcji, dla których je powołano i wzajemną komplementarność przesądzają o sprawności układu gospodarczego i wynikach. Przejawem słabej jakości instytucji są patologie życia gospodarczego, aktywność osób poszukujących renty i grup interesów (Klimczak, 2002, s. 495-523).

Ta część kosztów, która wiąże się z utrzymaniem sprawnych instytucji, nazywa się kosztami transakcyjnymi. Przyjmując, że system ekonomiczny to zbiór powiązanych ze sobą instytucji, które wyznaczają ramy i reguły działalności gospodarczej, za trafną trzeba uznać uwagę Kennetha Arrowa (1969: 1184), że koszty transakcyjne to „koszty funkcjonowania systemu gospodarczego". Dużą cześć tych kosztów ponosi państwo, którego obowiązkiem jest zapewnienie stabilnych i dobrze funkcjonujących ram prawnych i organizacyjnych dla podmiotów gospodarczych. Wzrost wydatków państwa z tym związanych znajduje odbicie w zjawisku nazwanym prawem Adolpha Wagnera, które głosi, iż wraz $z$ rozwojem gospodarczym rośnie udział wydatków publicznych $w$ PKB, co z kolei wymusza wzrost podatków (Wilkin, 2010, s. 26). Ograniczeniu kosztów transakcyjnych sprzyja doskonalenie instytucji, w tym instytucji państwa.

System wspierania zatrudnienia osób z niepełnosprawnościami stanowi element otoczenia instytucjonalnego tworzącego państwo, organizującego gospodarkę i społeczeństwo. Złożony $\mathrm{z}$ instytucji normujących wysokość ulg i obciążeń pracodawców, tworzących standardy tych podmiotów oraz państwa w relacjach wymiany na rynku politycznym, wprowadza ograniczenia, których przestrzeganie (lub też nie) pociąga za sobą powstanie kosztów transakcyjnych. Koszty te występują łącznie z instytucjami jako nieunikniona konsekwencja ograniczeń przez nie nakładanych. Traktowane są jako ich koszty uboczne, często niedostrzegane i pomijane $\mathrm{w}$ rachunku efektywności ekonomicznej, pomimo, iż wpływają na ogólny wynik działania całej gospodarki - w tym przypadku działania systemu wspierania zatrudnienia osób z niepełnosprawnościami. Są to koszty, które obejmują wszelką pomoc publiczną, kierowaną do pracodawców. Wymaga to również szerokich działań prawnych i ustawodawczych, dodatkowej pracy organów państwa i Państwowego Funduszu Rehabilitacji Osób Niepełnosprawnych (PFRON), kontrolnych, co składa się na łączne koszty koordynacji obranej polityki w tym zakresie, tj. na koszty transakcyjne. Im bardziej system obrasta kolejnymi przywilejami dla pracodawców oraz modyfikacjami (szczególnie mającymi charakter doraźny), tym większe ponosi koszty koordynacji.

Obecnie w Polsce mamy dwa sposoby wspierania zatrudniania osób z niepełnosprawnościami: sto- sowanie obligatoryjnego wskaźnika zatrudniania tych osób (tzw. metoda kwotowa), udzielanie dotacji oraz innych korzyści ze środków publicznych dla podmiotów zatrudniających osoby z niepełnosprawnościami. Wspomniana metoda kwotowa polega na nałożeniu na pracodawców zatrudniających powyżej 25 pracowników obowiązku zatrudnienia osób z niepełnosprawnościami w udziale 6\% załogi. Jeżeli pracodawca tego nie czyni, jest na mocy przepisów prawa zobowiązany do wpłacania „karnej wpłaty" na PFRON (Ustawa o rehabilitacji, rozdział 10). Druga metoda jest wsparcie podmiotów zatrudniających osoby $\mathrm{z}$ niepełnosprawnościami. Polega ona na udzielaniu dotacji ze środków PFRON, ulg i zaniechań podatkowych oraz udzielanie niskooprocentowanych pożyczek. Pracodawca może np. uzyskać zwrot kosztów: wyposażenia stanowiska pracy, wynagrodzenia osób z niepełnosprawnościami skierowanych do pracy przez urzędy pracy oraz szkoleń organizowanych przez pracodawców dla takich pracowników.

Przywileje w postaci zwolnień wpłat na PFRON i dotacji dla pracodawców są formami pomocy publicznej, których działanie uznaje się za szkodliwe ze względu na zakłócenie mechanizmu wolnego rynku i uczciwej konkurencji. Wykorzystanie wpłat na PFRON w funkcjach pozafiskalnych oznacza wyposażenie systemu wspierania zatrudnienia osób z niepełnosprawnościami w instytucje ulg i dotacji, które są sposobem ograniczania zawodności państwa, załatwiania spraw doraźnych, pokonywania skutków niepełnej informacji, których udostępnienie i wykorzystanie zwiększa koszty koordynacji. Wspieranie zatrudnienia niepełnosprawnych jest dowodem tego, że osiąganie różnych celów politycznych wymaga ręcznego sterowania za pomoca instrumentów quasi-fiskalnych. Im większe wykorzystanie narzędzi doraźnych, tym więcej kosztów koordynacji („tarcia”) w systemie gospodarczym. Świadczą one o słabości systemu wspierania zatrudnienia, który nie rozwiązuje problemów w ramach przypisanych mu funkcji i konieczne staje się naruszanie jego konstrukcji. Liczba i częstotliwość zmian wpływa na wielkość kosztów transakcyjnych, ponieważ rośnie aktywność działań dostosowawczych, powstaja nowe instytucje, których utrzymanie kosztuje. Nowe regulacje tworzą zapotrzebowanie i ofertę usług doradczych, szkoleń, pozyskiwania informacji, zabezpieczania itd. generując kolejne koszty transakcyjne tego systemu.

Niepożądanym efektem działania obowiązujących instytucji jest łamanie reguł formalnych i nieformalnych spowodowane oportunistycznymi reakcjami pracodawców na wprowadzane ograniczenia. Tworza one negatywne zjawiska fałszowania stanu zatrudnienia, celowego utrzymywania zaległości podatkowych na PFRON i ZUS. Ich skutkiem są utracone korzyści PFRON w postaci nieotrzymanych dochodów oraz straty dobrobytu, powiększające koszty funkcjonowania całego sytemu rehabilitacji zawodowej i wpierania zatrudniania osób z niepeł- 
nosprawnościami, a tym samym również gospodarki. Wysiłki zmierzające do ich wykrycia lub oszacowania absorbują pracę administracji rządowej i PFRON, z tego względu dane o skali tych zjawisk mogą być także użyte jako miary pośrednie kosztów transakcyjnych generowanych przez omawiany system.

Kategoria kosztów transakcyjnych najczęściej utożsamiana jest $\mathrm{z}$ poziomem mikroekonomicznym, ponieważ dorobek teorii koncentruje się na transakcjach rynkowych i relacjach menedżerskich. Rozszerzenie zastosowania kryterium kosztów transakcyjnych w ocenie instytucji na poziom makroekonomiczny i inne obszary stosunków społecznych jest zasługa Oliviera Williamsona - laureata nagrody Banku Szwecji im. Alfreda Nobla w dziedzinie ekonomii, który dowodzi, że każdy problem dotyczący wymiany można rozpatrywać z punktu widzenia oszczędności kosztów transakcyjnych, powstających $\mathrm{w}$ związku z zawieraniem kontraktu (Stiglitz, 2004, s. 388). Relacje miedzy państwem a przedsiębiorcą zatrudniającym osoby $\mathrm{z}$ niepełnosprawnościami przybierają formę kontraktu, w którym przedsiębiorąca w zamian za zatrudnianie niepełnosprawnych pracowników lub płacenie daniny na PFRON otrzymuje ochronę praw i porządek instytucjonalnoprawny. Państwo wywiązuje się z tego kontraktu przez stworzenie otoczenia instytucjonalnego. Zdolność do wypełniania funkcji przypisanych instytucjom i koszty transakcyjne, jakie one ze sobą niosą, są odpowiednimi kryteriami oceny jakości otoczenia instytucjonalnego państwa, uwzględniającymi zarówno skuteczność i sprawność zorganizowania systemu gospodarczego oraz społeczeństwa, jak i efektywność użycia do tego celu środków publicznych pochodzących z daniny płaconej do PFRON. Mając do wyboru różne kombinacje instytucji pełniących te same funkcje, lepszym rozwiązaniem jest to, które generuje mniejsze koszty transakcyjne (np. zatrudnienie niepełnosprawnych, czy tez płacenie daniny na PFRON). Kryterium wyboru publicznego „sprowadza się do wyboru układu instytucji minimalizującego koszty (lub maksymalizującego korzyści) życia w kolektywie" (Ząbkowicz, 2003, s. 813).

Istotną różnica między transakcjami zawieranymi na rynku dóbr, a kontraktem politycznym jest sposób wyceny wartości aktywów, które są przedmiotem wymiany. Na rynku dóbr wycena ta kształtuje się pod wpływem posiadanej informacji o gotowości nabywcy do zapłaty określonej ceny za dobro oraz gotowości producenta do jego sprzedaży po określonej cenie. Rynek polityczny rządzi się innymi regułami, zapadające na nim decyzje są wyborem publicznym, w którym przejawiaja się preferencje społeczne i osiągany jest kompromis między racjonalnością a sprawiedliwością. Efektem wyboru publicznego jest konstrukcja systemu wspierania zatrudnienia osób z niepełnosprawnościami skutkująca różnym stopniem poboru daniny na PFRON i rezygnacji państwa z określonej części potencjalnych wpływów na przykład podatkowych, do ZUS i innych organizacji (urzędów).

Optymalny system wspierania zatrudnienia osób z niepełnosprawnościami powinien maksymalizować dobrobyt społeczny oraz minimalizować koszty transakcyjne generowane przez jego strukturę instytucjonalną (niezbędne do zapewnienia działania i wypełniania funkcji regulacyjnych). Trzeba jednak zaznaczyć, iż obowiązujący system nie jest optymalny, (co najwyżej suboptymalny), powoduje zniekształcenia wywołane efektem substytucyjnym i straty dobrobytu skutkujące nieosiąganiem maksimum użyteczności. W wyniku decyzji politycznych przyjmowane są różne konstrukcje systemu wspierania zatrudnienia osób z niepełnosprawnościami, usiłujące przybliżyć go do ideału, jakim jest optimum Pareto ${ }^{3}$. Szczegółowe rozwiązania maja umożliwić osiaganie za pomoca wpłat na PFRON obranych celów politycznych, a zarazem godzenie efektywności i sprawiedliwości. Im więcej zawiłości, regulacji, odstępstw od reguły, tym większe koszty koordynacji działania systemu oraz jego wkomponowania w układ gospodarczy.

Obranie optimum Pareto za punkt wyjścia do oceny systemu wspierania zatrudnienia osób $\mathrm{z}$ niepełnosprawnościami wyznacza istotny podział kosztów transakcyjnych na niezbędne (bezpośrednie lub konieczne) i zbędne (niepożądane). Kryterium zasadności ponoszenia kosztów transakcyjnych tego systemu pozwala wyodrębnić pewne koszty nieuniknione dla jego funkcjonowania, odpowiadają one kosztom generowanym przez system optymalny. Pozostałe są kosztami niepożądanymi, wskazującymi na ile system odbiega od optymalnego. Powstają na skutek koordynacji działań wywołanych decyzjami politycznymi oraz słabej jakości instytucji państwa, jak również reakcji pracodawców.

Koszty transakcyjne systemu wspierania zatrudnienia są kosztami koordynacji, której celem jest utrzymanie odpowiedniego poziomu zatrudnienia niepełnosprawnych poprzez regulacje prawne i fiskalne. Koordynacja ta obejmuje różnego rodzaju działania wynikające z konieczności angażowania zasobów oraz wprowadzania rozwiązań godzących preferencje społeczne, co sprawia że koszty transakcyjne nie są jednorodne, mają złożoną strukturę, część z nich ma formę nakładów wyrażonych w jednostkach pieniężnych, a część występuje w postaci niemierzalnej straty dobrobytu społecznego ${ }^{4}$.

Podstawowym problemem, przed jakim stają badacze kosztów transakcyjnych jest ich operacjonalizacja i pomiar. Wynika to z trudności identyfikacji

\footnotetext{
3 Warto zauważyć, że wolna wymiana dóbr, przy założeniu braku istnienia kosztów transakcyjnych, prowadzi do efektywnej alokacji w sensie Alfredo Pareto. Co więcej, jeżeli alokacja nie jest efektywna w sensie Pareto, to można poprawić sytuację niektórych uczestników bez pogarszania sytuacji innych, co jest bardzo pożądane, za: D. Begg, S. Fischer, R. Dornbusch (2003), Mikroekonomia, PWE Warszawa, s. 431.

4 Termin dobrobyt społeczny jest standardowo wykorzystywany w dobrobycie ekonomicznym i wskazuje na etyczną wartość lub „dobroć” stanów interesów całej społeczności, za: A. Sen (1991), Welfare, preference and freedom. Journal of Econometrics, 50(1-2), p. 16.
} 
tych kosztów oraz z ich częściowo niepieniężnego charakteru, dlatego pewną przybliżoną, pośrednią miarą mogą być transfery z PFRON i profity z innych funduszy publicznych do pracodawców na rzecz wspierania zatrudnienia osób z niepełnosprawnościami oraz koszty koordynacji systemu.

Koszty bezpośrednie obejmują nakłady na utrzymanie struktury instytucjonalnej systemu wspierania zatrudnienia, na które składają się koszty: całego procesu legislacyjnego, przepływu informacji, funkcjonowania PFRON, szkolenia i organizowania administracji terenowej (gmin i powiatów), oprogramowania i formularzy pobierania danin na rzecz Funduszu. Miarą tych kosztów są wydatki z budżetu państwa i PFRON. Koszty niepożądane mają źródło w zawodności instytucji państwa. Zalicza się do nich koszty: spowodowane efektem ogłoszenia i przepływu informacji, błędnych decyzji PFRON i MRPiPS (Ministerstwa Rodziny Pracy i Polityki Społecznej), zabezpieczenia przed ryzykiem, uciążliwości wypełniana obowiązku wpłat. Są to koszty szkodliwe, obciążające budżet państwa i budżety prywatne. Ograniczenie zawodności organów państwa udostępnianiem ulg i wsparcia pracodawców powoduje wzrost nakładów we wszystkich pozycjach kosztów niezbędnych i niepożądanych na skutek skomplikowania prawa, jego stosowania i egzekwowania. Wykorzystując podejście Williamsona (Williamson, 1998, s. 57) jako podstawowe źródła kosztów transakcyjnych wyróżnić należy: ograniczoną racjonalność człowieka, którą można określić jako racjonalną w intencji ale w ograniczonym stopniu, co wynika przede wszystkim z trudności lub barier w dostępie do pełnego zakresu informacji potrzebnych do dokonania transakcji, upodobanie do oportunizmu, przejawiające się przedkładaniem subiektywnych celów niektórych uczestników procesu transakcji nad obiektywnymi celami transakcji, gdy identyfikacja tych uczestników jest utrudniona lub wymaga poniesienia nadmiernych kosztów, specyfikę aktywów wykorzystywanych w transakcji, co związane jest z potrzebą inwestycji w wyspecjalizowane zasoby, charakterystyczne dla rozpatrywanej transakcji.

\section{Podsumowanie: Pigou czy Coase?}

Można zatem zadać pytanie która z prezentowanych koncepcji bardziej odzwierciedla aktualny rynek pracy osób z niepełnosprawnościami w Polsce? Odpowiedz nie jest jednoznaczna. Na pierwszy rzut oka zadaje się wygrywać koncepcja Pigou. Niemniej teoremat Coase nie jest na pozycji straconej.

Przekładając tą analizę do praktyki gospodarczej możemy wysunąć parę wniosków. Po pierwsze, wysokość obecnych stawek daniny na PFRON (6\%) jest zdecydowanie wyższa w porównaniu do wielu krajów Unii Europejskiej. Po drugie dotacje i ulgi jaki przysługują pracodawcom osób z niepełnosprawnościami nie spełniają ich oczekiwań - co odzwierciedla poziom zatrudnienia. Są niższe od poziomu optymalnej stawki podatku Pigou, przez co nie istnieją bodźce ekonomiczne do zatrudniania osób z niepełnosprawnościami. Po trzecie zatrudnienie dotowane ze środków PFRON waha się w granicach 230-240 tys. osób. Stanowi to około $16 \%$ ogólnej liczby niepełnosprawnych pracujących. Upraszczając założenia - należy przypuszczać, że pozostała część tych osób (ok. 1,5 mln.) znalazła pracę dzięki negocjacjom w rozumieniu Coase. Widać zatem, że polityka rynku pracy oparta na założeniach podatku Pigou w zakresie aktywizacji osób z niepełnosprawnościami jest w świetle BAEL i tak niewystarczająca. Pracodawcy wolą płacić parapodatek na PFRON, niż zatrudnić takie osoby, a sami niepełnosprawni - pozostać biernymi zawodowo. W rezultacie zarówno niepełnosprawni, jak i ich pracodawcy nie mają zadowalających bodźców ekonomicznych do zmiany swoich zachowań, co prowadzi do powstania nieefektywności.

Rozwiązanie Pigou podkreśla niedoskonałości rynku oraz wskazuje potrzebę instytucji do regulowania rynku pracy, tak aby uzyskać odpowiedni poziom wskaźnika zatrudnienia osób z niepełnosprawnościami. Takie podejście wymaga gromadzenia skomplikowanych i szybko zmieniających się informacji, przełożenia informacji na podatek lub regulację oraz nałożenie podatku lub reguły na podmioty rynku pracy. W artykule rozważono tylko niektóre problemy związane z tym podejściem oraz wskazano, iż podatki Pigou nadal pozostają przedmiotem dyskusji, ale są wdrażane i wykorzystywane w praktyce.

Co zatem z teorematem Coase? W tym przypad$\mathrm{ku}$ analiza dotyczyła pozostałych rozwiązań instytucjonalnych na rynku pracy. Tam, gdzie koszty transakcji są niskie, a prawa własności są wyraźnie przypisane, proces rynkowy może doprowadzić do optymalnego rozwiązania. Rozwiązanie Coase przyjmuje zdecentralizowane, procesowe podejście, w którym strony biorące udział w tym procesie gromadzą własne informacje i wykorzystują je do formułowania umów, tak jak na każdym innym rynku. Jest zatem dynamiczne - jeśli warunki ulegną zmianie, strony mogą zmienić swoją umowę w następnym okresie obowiązywania umowy. Nie muszą czekać na wybory i zmiany w funkcjonowaniu instytucji.

Wydaje się zatem, że podejście Coase może zastosować, gdy na rynku pracy występuje mała liczba podmiotów, które zaangażowane w problem mogą dokonywać transakcji (De Alessi, 1998). Podejście zaproponowane przez Pigou wydaje się pasować do rynku pracy z dużą liczbą uczestników. Zanim jednak wyciągniemy wnioski dotyczące względnych zalet tych dwóch podejść, powinniśmy zdać sobie sprawę, że przypadki „dużej liczby uczestników” mogą stać się mniej liczne, gdy podmioty - uczestnicy runku pracy - stworzą stowarzyszenia lub związki.

Myśląc w kategorii Coase contra Pigou, powinniśmy również rozważyć cel dociekań Coase'a; chciał 
on zrozumieć świat, w którym koszty transakcji są pozytywne. Kiedy obserwujemy ten świat, widzimy bogaty zestaw instytucji. Zasady odpowiedzialności i zasady common law stanowią tylko niewielką część tego świata. Większość stanowi: kapitał, monitorowanie rynku kapitałowego oraz konkurencji, a także troska o społeczność. Widać zatem, że graczy na rynku pracy osób z niepełnosprawnościami jest wielu: rząd, pracodawcy, poszukujący pracy oraz inne organizacje. Są to instytucje tworzace koszty transakcyjne, które ograniczają bezpośrednie negocjacje w rozumieniu Coase. To właśnie ta część świata stanowiła credo jego rozważań.

Na pierwszy rzut oka, sugerowanie, że rząd powinien skupić się na sobie narzucając regulacje nakazowo-kontrolne jedynie na przedsiębiorstwa państwowe oraz pozostawić nieskrępowany niczym rynek pracy, wydaje się być receptą na Pigou. W założeniach implicite zakłada się, że centralne kierowanie zarządzane przez mądrych ekonomistów-optymistów doprowadzi do sukcesu. Jednak jeśli teoria wyboru publicznego miałaby czegokolwiek nauczyć, to tego, że rząd jest endogeniczny dla ekonomii politycznej. Kiedy ma się do czynienia z życzliwą dyktaturą to w zasadzie nie ma władzy i regulacji. Sam proces determinuje efekty i właśnie w procesie analizy Coase ma przewagę nad Pigou.

Aby uniknąć pułapki Pigou, musimy skupić się na podstawowych zasadach, regułach konstytucyjnych, które ustalają oraz uznają prywatnie reguły własności, o których mówi Richard Wagner (1998).
Kiedy prawo zostanie przyjęte w drodze konsensusu, rola rządu staje się jasna. Rząd ma konstytucyjny obowiązek ochrony praw własności i w związku z tym zarządza własnymi sprawami, aby niepożądane koszty nie były nakładane na obywateli i pracodawców osób z niepełnosprawnościami. Kiedy fundamentalna ochrona konstytucyjna zostaje naruszona przez politykę, znajdujemy się na pełnym bezkresnym morzu. Zamiast powoływać się na rozwiązania Pigou, które naruszaja konstytucyjną ochronę praw własności, powinniśmy wezwać do ustanowienia porządku konstytucyjnego, który zminimalizuje potrzebę wprowadzenia podatku Pigou i zmaksymalizuje obszar dla negocjacji Coase.

Żyjemy w świecie stworzonym przez prawo i zasady społeczne, czyli instytucje. Między polityką a gospodarką panuje napięcie. Na prawa własności i proces rynkowy wpływają siły polityczne, które kształtują nasz system społeczny. Inicjatywy polityczne inspirowane celowymi grupami interesu spotykają się z nieokiełznanymi siłami rynku, na który narzucane są kontrakty i prawa własności. Instytucje zajmujące się aktywizacją osób z niepełnosprawnościami, które pojawiają się na tym rynku, napotykają owe surowe siły polityczne i zakorzenioną biurokrację. Każdego dnia nowy świat wyłania się z tych spotkań. Część instytucji, które obserwujemy, to pochodne teorematu Coase; kolejna część to pochodne podatku Pigou. U podstaw tego wszystkiego leży system praw własności, który wciąż ewoluuje.

\section{Literatura:}

1. Arrow, K.J. (1969). Agency and market. W: K.J. Arrow, M.D. Intrilligator (red.), Handbook of Mathematical Economics (s. 1183-1195). Amsterdam: Elsevier.

2. Badanie Aktywności Ekonomicznej Ludności BAEL (2017). GUS: Warszawa. Pobrane z: http://www.niepelnosprawni.gov.pl/p,81,bael

3. Begg, D., Fischer, S., Dornbusch, R. (2003). Mikroekonomia. Warszawa: PWE.

4. Bovenberg, A.L., Goulder, H. (1969). Optimal Environmental Taxation in the Presence of Other Taxes: General Equilibrium Analyses. American Economic Review, 86(4), 985-1006.

5. Coase, R. (1959). The Federal Communications Commission. Journal of Law and Economics, 2, 1-40. https://doi.org/10.1086/466549

6. Coase, R. (1960). The Problem of Social Cost. Journal of Law and Economics, 3, 1-44. https://doi.org/10.1086/466560

7. Coase, R. (1988). The Firm, the Market and the Law. Chicago: University of Chicago Press.

8. Davies, W. (2014), The Limits of Neoliberalism: Authority, Sovereignty and the Logic of Competition. London: SAGE. https://doi.org/10.4135/9781473906075

9. De Alessi, L. (1998), Reflections on Coase, cost and efficiency. W: B. Monissen, J. M. Buchanan (red.), The Economist' Vision (s. 91-114). Franfurt: Campus Verlag.

10. Hayek, F.A. (1969). Freiburger Studien. Gesammelte Aufsätze. Tübingen: JCB Mohr.

11. Klimczak, G. (2002). Działania grup interesów okresie transformacji - teoria i zastosowanie. Ekonomista, 4, 495-523.

12. Kubisz, J. (2017). Teoria Ronalda Coase’a a własność i odpowiedzialność za szkodę. W: M. Machaj (red.) Pod prąd głównego nurtu ekonomii (s. 49-72). Warszawa: Instytut Ludwiga von Misesa.

13. Mankiw, G.N., Taylor, M.P. (2009). Mikroekonomia. Warszawa: PWE.

14. Merrill, T.W., Smith, H.E. (2017). Property: Principles and Policies, University Casebook Series (3rd ed.). St. Paul: Foundation Press.

15. Pezzey, J.C.V. (1989). Economic Analysis of Sustainable Growth and Sustainable Development. Washington: World Bank, Environment Department Working Paper No.15. 
16. Pigou, A.C. (1920). The Economics of the Welfare. London: Macmillan and co.

17. Sen, A. (1991). Welfare, preference and freedom. Journal of Econometrics, 50(1-2), 15-29. https://doi. org/10.1016/0304-4076(91)90087-T

18. Stiglitz, J.E. (2004). Ekonomia sektora publicznego. Warszawa: PWN.

19. Tietenberg, T. (1992). Environmental and Natural Resource Economics, New York: HarperCollins.

20. Ustawa z dnia 27 sierpnia 1997 r. o rehabilitacji zawodowej i społecznej oraz zatrudnianiu osób niepełnosprawnych, Dz. U. 1997, Nr 123, poz 777.

21. Wilkin, J. (2010). Słabość państwa w jego relacji do gospodarki i słabość ekonomicznej teorii państwa. Zarządzanie Publiczne, 1(11), 25-35.

22. Williamson, O.E. (1998). Ekonomiczne instytucje kapitalizmu. Firmy, rynki, relacje kontraktowe. Warszawa: PWN.

23. Williamson, O.E. (2000). The New Institutional Economics: Taking Stock, Looking Ahead. Journal of Economic Literature, 38, 595-613. https://doi.org/10.1257/jel.38.3.595

24. Ząbkowicz, A. (2003). Współczesna ekonomia instytucjonalna wobec głównego nurtu ekonomii. Ekonomista, 6, 795-823. 